\title{
Effectiveness of Early Ambulation on Post Operative Recovery among the Women with Caesarean Section (CS)
}

\author{
Reema Paul1, Priya J. P. Narayan², Harleen Kaur ${ }^{2}$ \\ ${ }^{1}$ M.Sc. Nursing student, ${ }^{2}$ Assistant professor \\ ${ }^{1}$ Himalayan College of nursing, SRHU, Dehradun, Uttarakhand, India \\ 2Fundamental of Nursing Department Himalayan College of Nursing, SRHU, Dehradun, Uttarakhand, India
}

\begin{abstract}
How to cite this paper: Reema Paul | Priya J. P. Narayan | Harleen Kaur "Effectiveness of Early Ambulation on Post Operative Recovery among the Women with Caesarean Section (CS)" Published in International Journal of Trend in Scientific Research and Development (ijtsrd), ISSN: 24566470, Volume-3 | Issue-3 , April 2019, pp.851-855, URL: https://www.ijtsrd.c om/papers/ijtsrd23 067.pdf

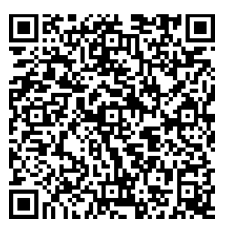

IITSRD23067

Copyright (C) 2019 by author(s) and International Journal of Trend in Scientific Research and Development Journal. This is an Open Access article distributed under

the terms of the Creative Commons

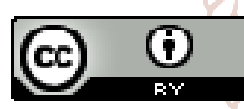

Attribution License (CC BY 4.0) (http://creativecommons.org/licenses/ by $/ 4.0$ )
\end{abstract}

\section{INTRODUCTION}

Background

Welcoming to the world where health starts early. Childbirth is seen as an vital life occasion. It may be a common, ordinary physiological marvel which presents modem encounters in women's regenerative life. The child birth occasions got extraordinary physiological, enthusiastic and social effect to the women and her family. ${ }^{1}$

During the postnatal period women perceive so many complication. Its needed to restore women health status which can also improve post operative recovery.

Early ambulation in post operative period is the key to get rapid and maximum muscle function and restoration of mother's health. Ambulation helps to decrease most of the complications by ensuring good blood circulation, promoting gastric motility, enhancing respiration, decreasing chances of thrombophlebitis, preventing orthostatic hypotension, improving the physical strength etc. A complete ambulation program done at this time can prevent complications in later life. $^{2}$

\section{ABSTRACT}

Background- Welcoming to the world where health starts early. Childbirth is seen as a vital life occasion. During the postnatal period women perceive so many complications. It's needed to restore women health status which can also post operative recovery. Early ambulation help the post CS women to perform altivity of daily living effectively Objectives - To assess the effect of early ambulation on post operative recovery of women with CS. Method - A quasi experimental study was conducted on 60samples (30experimental and werestat we randomly assignment to experimental and control. Result - Experimental group showed gradual improvement in the post operative recovery from day-I- 23.77 \pm 2.763 , day-II- $35.37 \pm 2.498$ and day-III- $45.67 \pm 2.564$ similarly in control group also there was improvement in the post operative recovery day-I- $18.17 \pm 1.147$, in day-II- $22.53 \pm 2.776$ and day-III- $32.97 \pm 2.671$ but compare to control group the post operative recovery was much more faster in experimental group. clusion- Study concluded that experimental group has gradually improving the post operative recovery compared to the control group. It showed that early KEYWORDS: Caesarean Section (CS), Activity of daily living (ADL)

\section{PURPOSE}

To add early post CS recovery thus lead to a better positive outcome in post CS women

\section{OBJECTIVES}

To assess the effect of early ambulation on post operative recovery of women with CS.

\section{MATERIALS AND METHODS -}

A quasi experimental research design was used to conduct the study among 60 women (30 in experimental group and 30 in the control group) with caesarean section (CS). Study was conducted at in a postnatal ward of Himalayan hospital, Dehradun. A convenient sampling technique was used to collect the data. The group were randomly assign into experimental and control group. Tool is consist in 3 section i.e. Section -A- Demographic variables, Section- BStructured Nursing Assessment sheet on postoperative recovery, Section- C- Likert scale on activity daily living on postoperative recovery. 
International Journal of Trend in Scientific Research and Development (IJTSRD) @ www.ijtsrd.com eISSN: 2456-6470

RESULT

Table no:-1 Frequency (f) and percentage (\%) distribution according to their Demographic variables

\begin{tabular}{|c|c|c|c|c|c|c|c|}
\hline \multirow{2}{*}{$\begin{array}{c}\text { S. } \\
\text { No. }\end{array}$} & \multirow{2}{*}{ Demographic Variables } & \multicolumn{2}{|c|}{ Experimental group } & \multicolumn{2}{|c|}{ Control group } & \multicolumn{2}{|c|}{ Homogeneity } \\
\hline & & $\mathrm{f}$ & Percentage & $\mathrm{f}$ & Percentage & $\chi^{2}$ & p-value \\
\hline 1. & $\begin{array}{l}\text { Age (in year) } \\
\text { a) 20-25 year } \\
\text { b) 26-30 year } \\
\text { c) } 31-35 \text { year }\end{array}$ & $\begin{array}{l}12 \\
11 \\
7 \\
\end{array}$ & $\begin{array}{l}40 \% \\
37 \% \\
23 \% \\
\end{array}$ & $\begin{array}{l}8 \\
11 \\
11 \\
\end{array}$ & $\begin{array}{l}26.6 \% \\
36.6 \% \\
36.6 \% \\
\end{array}$ & 0.129 & $0.246^{£}$ \\
\hline 2. & $\begin{array}{l}\text { Education } \\
\text { a) No formal education } \\
\text { b) Primary education } \\
\text { c) Secondary education } \\
\text { d) Higher secondary } \\
\text { e) Graduation \& above }\end{array}$ & \begin{tabular}{|l|}
1 \\
2 \\
1 \\
6 \\
20 \\
\end{tabular} & $\begin{array}{l}3 \% \\
7 \% \\
3 \% \\
20 \% \\
67 \% \\
\end{array}$ & $\begin{array}{l}1 \\
1 \\
3 \\
11 \\
14\end{array}$ & $\begin{array}{l}3 \% \\
3 \% \\
10 \% \\
37 \% \\
47 \% \\
\end{array}$ & 17.997 & $0.838^{\#}$ \\
\hline 3. & $\begin{array}{l}\text { Occupation } \\
\text { a) Housewife } \\
\text { b) Working }\end{array}$ & \begin{tabular}{|l}
23 \\
7
\end{tabular} & $\begin{array}{l}77 \% \\
33 \% \\
\end{array}$ & $\begin{array}{l}25 \\
5\end{array}$ & $\begin{array}{l}83 \% \\
17 \% \\
\end{array}$ & 2.311 & $0.860^{\#}$ \\
\hline 4. & $\begin{array}{l}\text { Type Of Family } \\
\text { a) Joint } \\
\text { b) Nuclear }\end{array}$ & \begin{tabular}{|l}
22 \\
8
\end{tabular} & $\begin{array}{l}73 \% \\
27 \% \\
\end{array}$ & $\begin{array}{l}24 \\
6\end{array}$ & $\begin{array}{l}80 \% \\
20 \% \\
\end{array}$ & & $0.155^{\#}$ \\
\hline 5. & $\begin{array}{l}\text { Age at marriage } \\
\text { a) } 18-25 \text { year } \\
\text { b) } 26-35 \text { year }\end{array}$ & \begin{tabular}{|l|}
23 \\
7 \\
\end{tabular} & $\begin{array}{l}77 \% \\
23 \% \\
\end{array}$ & $\begin{array}{l}21 \\
9 \\
\end{array}$ & $\begin{array}{l}70 \% \\
30 \% \\
\end{array}$ & 0.737 & $0.142^{\epsilon}$ \\
\hline 6. & $\begin{array}{l}\text { Duration of married life } \\
\text { a) }>1 \text { year } \\
\text { b) }>5 \text { year } \\
\text { c) }>10 \text { year }\end{array}$ & $\begin{array}{l}16 \\
12 \\
2\end{array}$ & $\begin{array}{l}53 \% \\
40 \% \\
7 \%\end{array}$ & $\begin{array}{l}17 \\
9 \\
4\end{array}$ & $\begin{array}{l}57 \% \\
30 \% \\
13 \% \\
\end{array}$ & 0.202 & $0.902^{ \pm}$ \\
\hline 7. & $\begin{array}{l}\text { Area of living } \\
\text { a) Rural } \\
\text { a) Urban }\end{array}$ & $\begin{array}{l}12 \\
18 \\
\end{array}$ & $\begin{array}{l}40 \% \\
60 \% \\
\end{array}$ & 12 & $\begin{array}{l}40 \% \\
60 \% \\
\end{array}$ & 0.0001 & $1.000^{¥}$ \\
\hline 8. & $\begin{array}{l}\text { Dietary habit } \\
\text { a) Vegetarian } \\
\text { b) Non-vegetarian }\end{array}$ & $\begin{array}{l}11 \\
19 \\
\end{array}$ & $\begin{array}{l}37 \% \text { urnal } \\
63 \% \text { ntific }\end{array}$ & $\begin{array}{l}14 \\
16\end{array}$ & $\begin{array}{l}4 \% \\
53 \%\end{array}$ & 0.0001 & $1.000^{¥}$ \\
\hline 9. & $\begin{array}{l}\text { Perform some specific daily activity c } \\
\text { pregnancy } \\
\text { b) Yes } \\
\text { c) No }\end{array}$ & $\begin{array}{l}\text { esea } \\
12 \text { eld } \\
18\end{array}$ & $\begin{array}{l}\text { ch and } \\
40 \% \text { nt } \\
60 \% \\
\end{array}$ & $\begin{array}{l}6 \\
6 \\
24 \\
\end{array}$ & $\begin{array}{l}20 \% \\
80 \% \\
\end{array}$ & & $1.000^{\#}$ \\
\hline 9.1 & $\begin{array}{l}\text { If yes which kind of physical activity } \\
\text { a) Yoga } \\
\text { b) Walking } \\
\text { c) Meditation } \\
\text { d) Cycling } \\
\text { e) Any other }\end{array}$ & $\begin{array}{l}\mathrm{N}-12 \\
5 \\
7 \\
0 \\
0 \\
0\end{array}$ & $\begin{array}{l}17 \% \\
23 \% \\
0 \\
0 \\
0\end{array}$ & $\begin{array}{l}\mathrm{N}-6 \\
1 \\
5 \\
0 \\
0 \\
0\end{array}$ & $\begin{array}{l}3 \% \\
17 \% \\
0 \\
0 \\
0\end{array}$ & & \\
\hline 10. & $\begin{array}{l}\text { Health related issues } \\
\text { a) Yes } \\
\text { b) No }\end{array}$ & \begin{tabular}{|l}
6 \\
24 \\
\end{tabular} & $\begin{array}{l}20 \% \\
8 \mathrm{t} 0 \% \\
\end{array}$ & $\begin{array}{l}2 \\
28 \\
\end{array}$ & $\begin{array}{l}7 \% \\
93 \% \\
\end{array}$ & & $1.000^{\#}$ \\
\hline 11. & $\begin{array}{l}\text { Type of LSCS } \\
\text { a) Elective } \\
\text { b) Emergency }\end{array}$ & $\begin{array}{l}11 \\
19 \\
\end{array}$ & $\begin{array}{l}37 \% \\
63 \% \\
\end{array}$ & $\begin{array}{l}12 \\
18 \\
\end{array}$ & $\begin{array}{l}40 \% \\
60 \% \\
\end{array}$ & & $1.000^{\#}$ \\
\hline 12. & $\begin{array}{l}\text { Gestation age } \\
\text { a) }<35 \text { weeks } \\
\text { b) }>37 \text { weeks } \\
\end{array}$ & \begin{tabular}{|l}
7 \\
23 \\
\end{tabular} & $\begin{array}{l}23 \% \\
77 \% \\
\end{array}$ & \begin{tabular}{|l}
4 \\
26 \\
\end{tabular} & $\begin{array}{l}13 \% \\
87 \% \\
\end{array}$ & 0.032 & $0.858^{¥}$ \\
\hline 13. & $\begin{array}{l}\text { Parity } \\
\text { a) Primi } \\
\text { b) Multi }\end{array}$ & $\begin{array}{l}18 \\
12 \\
\end{array}$ & $\begin{array}{l}60 \% \\
40 \% \\
\end{array}$ & $\begin{array}{l}10 \\
20 \\
\end{array}$ & $\begin{array}{l}33 \% \\
67 \% \\
\end{array}$ & 0.156 & $.693^{¥}$ \\
\hline 13.1 & $\begin{array}{l}\text { Previous delivery (if multi ) } \\
\text { a) LSCS } \\
\text { b) Forceps } \\
\text { c) NVD } \\
\text { d) Vacuum }\end{array}$ & $\begin{array}{l}\mathrm{N}-12 \\
8 \\
0 \\
4 \\
0 \\
\end{array}$ & \begin{tabular}{|l|}
$66 \%$ \\
0 \\
$33 \%$ \\
0 \\
\end{tabular} & $\begin{array}{l}\mathrm{N}-20 \\
15 \\
0 \\
4 \\
1\end{array}$ & $\begin{array}{l}75 \% \\
0 \\
20 \% \\
5 \% \\
\end{array}$ & & \\
\hline 13.2 & $\begin{array}{l}\text { Type of anesthesia (If LSCS) } \\
\text { a) General } \\
\text { b) Local } \\
\text { c) Spinal } \\
\text { d) Epidural }\end{array}$ & $\begin{array}{l}\mathrm{N}-8 \\
0 \\
0 \\
8 \\
0 \\
\end{array}$ & $\begin{array}{l}0 \\
0 \\
100 \% \\
0 \\
\end{array}$ & $\begin{array}{l}\mathrm{N}-15 \\
0 \\
0 \\
15 \\
0 \\
\end{array}$ & $\begin{array}{l}0 \\
0 \\
100 \% \\
0 \\
\end{array}$ & & \\
\hline
\end{tabular}

$\mathrm{df}_{1}=3.841$, at $\mathrm{p}<0.005, \mathrm{df}_{4}-9.49$, at $\mathrm{p}<0.005$

Chi-square, ${ }^{\#}$ Fisher's exact, ${ }^{\ddagger}$ Yate’s correction and, ${ }^{\ddagger}$ Independent t-test 
Table no 1 showed the frequency and percentage distribution of socio- demographic characteristics of CS women. Data revealed that most of the mothers were in a age group of $20-25$ year $(12,40 \%)$ in $26-30$ year of mother is $37 \%$ and in $30-35$ year of mother is $23 \%$ in experimental group \& in control group the age group of mother were $20-25$ is $27 \%$, in $26-30$ year and 31-35 year $(11,37 \%)$ In education most of the mother's in experimental were graduated \& above (20) $67 \%$ and in control group were (14) $47 \%$. In view of occupational status most of the mothers were housewife (23) $77 \%$ in experiment group whereas (25) 83\% in control group. In the type of family most of the mother's from joint family (22)73\% in experimental group \&in the control group most of the mother were from joint family (24) $80 \%$. In the age at marriage most of the mother in experimental group were 18-23year (23)77\% and in control group 18-23 year (21)70\%. In the duration of marriage in experimental group most of the mother having $>1$ year of duration (16) $53 \%$ in the control group most of the mother were also having $>1$ year of duration (17)57\%. In the area of living most of the mothers were from urban area(18)60\% in both group. In the perform some specific daily activity in that most of the mother's say 'no' (18) 60\%. That they are not performing some specific daily activity in experimental group \& in control group also most of the mother says 'no' (24) $80 \%$. In the health related issue most of the mother were not having any health related issues (24) 30\% in experimental group \& in control group also (28) 93\% mother not having any health related issues. In dietary pattern most of the mother were non- vegetarian (19) $63 \%$ in experimental group \& in control group also most of the mother were non-vegetarian (16)53\% . in type of LSCS most of the mother's were undergone emergency LSCS (19) 63\% in experimental group \& in control group also most of the mother's were undergone emergency LSCS(18) 60\%. In gestation age most of the mother's were delivered at the gestation age of $>37$ weeks (23) $77 \%$ \& in the control group also most of the mother were at the gestation age of $>37$ weeks (26) $87 \%$. In the parity most of the mother were primi (18)60\% in experimental group \& control group also most of the mother's were primi (20) $67 \%$.

The homogeneity Chi square, Fishers exact, Yate's correction and Independent t-test was performed to find the homogeneity between experimental and control groups. It revealed that there was no significant difference found between both the group (experimental and control group) in terms of distribution of age ( $\mathrm{t}=0.129 ; \mathrm{p}=0.246)$, educational status $\left(\chi^{2}=17.997 ; \mathrm{p}=0.838\right)$, occupational status $\left(\chi^{2}=2.311 ; p=0.860\right)$, type of family ( $\left.p=0.155\right)$, age at marriage $(t=0.737 ; p=0.142)$, Duration of married life $(t=0.202 ; p=0.902)$ area of living $\left(\chi^{2}=0.0001 ; p=1.00\right)$, Perform some specific daily activity $(p=1.00)$, Health related issues $(p=1.00)$, Dietary pattern $\left(\chi^{2}=0.001 ; p=1.00\right)$ Type of CS $(p=1.00)$ gestational age $\left(\chi^{2}=0.032 ; p=0.858\right)$, parity $\left(\chi^{2}=0.156 ; p=0.693\right)$

Hence it interpreted that study participants in both group (experimental and control group) were homogenous at the level $\mathrm{p}=$ $<0.005$.

Table no-2 frequency ( $f$ ) and percentage (\%) distribution of Base line data after 24 hours of CS

\begin{tabular}{|c|c|c|c|c|c|}
\hline \multirow{2}{*}{ S. No. } & \multirow{2}{*}{ Variables } & \multicolumn{2}{|c|}{ Experimental group } & \multicolumn{2}{|c|}{ Control group } \\
\hline & & f & Percentage & $\mathrm{F}$ & Percentage \\
\hline 1. & $\begin{array}{l}\text { Vital signs } \\
\text { a) Normal } \\
\text { b) Abnormal }\end{array}$ & $\begin{array}{l}26^{5} \\
4 \\
\end{array}$ & $\begin{array}{l}847 \% \\
13 \%\end{array}$ & 29 & $\begin{array}{l}97 \% \\
3 \%\end{array}$ \\
\hline 2. & $\begin{array}{l}\text { Total Urine Output } \\
\text { a) }<150 \mathrm{ml} \\
\text { b) } 150-300 \mathrm{ml} \\
\text { c) } 301-450 \mathrm{ml} \\
\text { d) }>450 \mathrm{ml}\end{array}$ & 30 & $100 \%$ & 30 & $100 \%$ \\
\hline 3. & $\begin{array}{l}\text { Moving in bed } \\
\text { a) Yes } \\
\text { b) No }\end{array}$ & $\begin{array}{l}21 \\
9 \\
\end{array}$ & $\begin{array}{l}70 \% \\
30 \% \\
\end{array}$ & $\begin{array}{l}15 \\
15 \\
\end{array}$ & $\begin{array}{l}60 \% \\
40 \% \\
\end{array}$ \\
\hline 4. & $\begin{array}{l}\text { Passed flatus } \\
\text { a) Yes } \\
\text { b) No }\end{array}$ & $\begin{array}{l}18 \\
12\end{array}$ & $\begin{array}{l}60 \% \\
40 \% \\
\end{array}$ & $\begin{array}{l}15 \\
15\end{array}$ & $\begin{array}{l}50 \% \\
50 \%\end{array}$ \\
\hline 5. & $\begin{array}{l}\text { Initiation of breastfeeding } \\
\text { a) Yes } \\
\text { b) No }\end{array}$ & $\begin{array}{l}26 \\
4 \\
\end{array}$ & $\begin{array}{l}87 \% \\
13 \% \\
\end{array}$ & $\begin{array}{l}16 \\
14 \\
\end{array}$ & $\begin{array}{l}53 \% \\
47 \% \\
\end{array}$ \\
\hline
\end{tabular}

Table no-2 Showed the frequency and percentage distribution of structured nursing assessment sheet (baseline data) of participants after 24 hour of CS. Regarding vital signs most of participants having normal vital signs in experimental group 26 (87\%) and control group 29 (97\%). Regarding total urine output (100\%) all participants in both group having more than 450 $\mathrm{ml}$ urine output. Regarding moving in bed majority $21(70 \%)$ of the participants able to move in bed in experimental group and half $15(50 \%)$ of the participants in the control group. Regarding passed flatus more than half $18(60 \%)$ of the participants passed flatus in experimental group and half $15(50 \%)$ of the participants moving in bed in the control group. Regarding initiation of breast feeding most 26(86.66\%) of the participants initiated breastfeeding in the experimental group where as more than half 16 (53.3\%) of the participants initiated the breast feeding in the control group. 


\begin{tabular}{|c|c|c|c|c|c|}
\hline \multirow{2}{*}{$\begin{array}{c}\text { S. } \\
\text { No. }\end{array}$} & \multirow{2}{*}{ Variables } & \multicolumn{2}{|c|}{ Experimental group } & \multicolumn{2}{|c|}{ Control group } \\
\hline & & f & Percentage & F & Percentage \\
\hline 1. & $\begin{array}{l}\text { Number of analgesic required } \\
\text { a) Nil } \\
\text { b) Once a day } \\
\text { c) Twice a day } \\
\end{array}$ & 30 & $100 \%$ & 30 & $100 \%$ \\
\hline 2. & $\begin{array}{l}\text { Duration of urinary catheter placed after caesarean section for } \\
\text { a) One day } \\
\text { b) Two days } \\
\text { c) Three days } \\
\text { d) More than three days }\end{array}$ & $\begin{array}{l}22 \\
8\end{array}$ & $\begin{array}{l}73 . \% \\
27 \%\end{array}$ & $\begin{array}{l}7 \\
23 \\
\end{array}$ & $\begin{array}{l}23 \% \\
77 \%\end{array}$ \\
\hline 3. & $\begin{array}{l}\text { Self-void after removal of catheter } \\
\text { a) }<1 \text { hours } \\
\text { b) } 1-2 \text { hours } \\
\text { c) }>2 \text { hours } \\
\text { d) Not removed } \\
\end{array}$ & $\begin{array}{l}20 \\
9 \\
1\end{array}$ & $\begin{array}{l}67 \% \\
30 \% \\
3 \%\end{array}$ & $\begin{array}{l}6 \\
1\end{array}$ & $\begin{array}{l}20 \% \\
3 \% \\
77 \% \\
\end{array}$ \\
\hline 4. & $\begin{array}{l}\text { Breast feeding and Holding baby independently after caesarean } \\
\text { section } \\
\text { e) Day-1 } \\
\text { f Day-2 } \\
\text { g) Day-3 } \\
\text { a) Not done } \\
\end{array}$ & $\begin{array}{l}4 \\
21 \\
5\end{array}$ & $\begin{array}{l}13 \% \\
70 \% \\
17 \%\end{array}$ & $\begin{array}{l}0 \\
9 \\
15 \\
6 \\
\end{array}$ & $\begin{array}{l}30 \% \\
50 \% \\
20 \% \\
\end{array}$ \\
\hline 5. & $\begin{array}{l}\text { Start of oral intake } \\
\text { a) Day-1 } \\
\text { b) Day-2 } \\
\text { c) Day-3 }\end{array}$ & $\begin{array}{l}2 \\
22 \\
6 \\
\end{array}$ & $\begin{array}{l}7 \% \\
73 \% \\
20 \% \\
\end{array}$ & $\begin{array}{l}15 \\
15 \\
\end{array}$ & $\begin{array}{l}50 \% \\
50 \%\end{array}$ \\
\hline
\end{tabular}

Table -3 Data in above table showed the day wise assessment score of post operative recovery among women with CS. In the number of analgesic required after CS all the women had taken twice prescribed dose of analgesic in both the groups till $3^{\text {rd }}$ post operative day. In the duration of catheter placed after CS majority 22 (73\%) of the women removed catheter in $2^{\text {nd }}$ post operative day in experimental group where as in control group majority $23(77 \%)$ of the women not removed catheter till 3rd post operative day. In self void after removal of catheter more than half $20(67 \%)$ of the women void $<1$ hour in experimental group where as in control group majority $23(77 \%)$ of the women had not removed catheter till 3ed post operative day. In the breast feeding and holding baby independently after caesarean section majority $21(70 \%)$ of the women had done at $2^{\text {nd }}$ post operative day where as in control group half of $15(50 \%)$ the women had independently hold baby and breast fed baby at $3^{\text {rd }}$ post operative day. In start of oral intake majority $22(73 \%)$ of the women had started oral intake at $2^{\text {nd }}$ post operative day in experimental group where as in control group most $15(50 \%)$ of the women started oral intake at $3^{\text {rd }}$ post operative day.

Hence it interpreted that the experimental group post operative recovery was much higher and early than control group which showed that intervention was effective to improve the post operative recovery

Objective -1- To assess the effect of early ambulation on post operative recovery of women with CS

$\mathbf{H}_{\mathbf{o}^{-}}$There would be no significant difference in post operative recovery of post CS women in experimental group \& control group

$\mathbf{H}_{\mathbf{1}^{-}}$There would be significant difference in post operative recovery of post CS women in experimental group \& control group

Table- 4 Comparison of post operative recovery between experimental group and control group after 24 hour of CS $\mathrm{N}=60$

\begin{tabular}{|c|c|c|c|c|}
\hline \multirow{2}{*}{ Groups } & \multicolumn{2}{|c}{ Post operative recovery (Mean \pm SD ) } & \multirow{2}{*}{ F value (p value $)^{x}$} \\
\cline { 2 - 5 } & $\mathbf{0 1 ( D a y - 1 )}$ & $\mathbf{0 2}($ Day-2) & 03(Day-3) & \\
\hline Experimental group & $23.77 \pm 2.763$ & $35.37 \pm 2.498$ & $45.67 \pm 2.564$ & $556.408(0.0001)$ \\
\hline Control group & $18.17 \pm 1.147$ & $22.53 \pm 2.776$ & $32.97 \pm 2.671$ & $456.5(0.0001)$ \\
\hline t- value (p value) $\omega$ & $10.253(0.0001)$ & $18.822(0.0001)$ & $18.785(0.0001)$ & \\
\hline
\end{tabular}

${ }^{\omega}$ Independent $t-$ test ${ }^{x}$ Repeated measure ANOVA test $t_{58}=2.00, p<0.05$

Table no -4 - Data in above table showed comparison of mean and standard deviation score within the group and between the group according to post operative recovery score in experimental group and control group. Day wise comparison of within the group was calculated using repeated measure ANNOVA and the obtained F value was 556.408 in experimental group where as in control group F Value was 456.5 at the level of 0.0001 in both the groups, which showed that experimental group day wise difference is much more than control group.

For the days wise comparison between the group, Women in experimental group showed gradual improvement in the post operative recovery from day-I- $23.77 \pm 2.763$, day-II- $35.37 \pm 2.498$ and day-III- $45.67 \pm 2.564$ similarly in control group also 
there was improvement in the post operative recovery day-I- $18.17 \pm 1.147$, in day-II- $22.53 \pm 2.776$ and day-III- $32.97 \pm 2.671$ but compare to control group the post operative recovery was much more faster in experimental group. The same was supported by calculating Independent ' $t$ '-test. The obtained $t$ value was day-I- $t=10.253$, day-II- $t=18.822$ and day-III- $t=$ 18.785 , and overall $p$ value 0.0001 which was more than the table value which indicated that there was significant difference found in both the groups Thus it can interpreted that calculated ' $t$ ' value is more than the tabulated value which showed that intervention was effective to improve the post operative recovery.

Hence, the null hypothesis was rejected and the research hypothesis was accepted. Thus it can be interpreted that experimental group have gradual improvement in post operative recovery as compared to the control group. It showed that experimental group intervention was effective to improve the post operative recovery.

\section{DISCUSSION- \\ Objective -1- To assess the effect of early ambulation on post operative recovery of women with CS}

The present study finding shows that comparison of post operative recovery score (activity daily living) between both group shows post operative recovery between experimental group and control group. Experimental group showed gradual improvement in the post operative recovery from day-I- $23.77 \pm 2.763$, day-II- $35.37 \pm 2.498$ and day-III$45.67 \pm 2.564$ similarly in control group also there was improvement in the post operative recovery day-I- $18.17 \pm$ 1.147, in day-II- $22.53 \pm 2.776$ and day-III- $32.97 \pm 2.671$ but compare to control group the post operative recovery was much more faster in experimental group. The same was supported by calculating Independent's'-test. The obtained $t$ value was day-I- $\mathrm{t}=10.253$, day-II- $\mathrm{t}=18.822$ and day-III- $\mathrm{t}=$ 18.785 , and overall $p$ value 0.0001 which was more than the table value which indicated that there was significant difference found in both the groups Thus it can interpreted that calculated ' $\mathrm{t}$ ' value is more than the tabulated value which showed that intervention was effective to improve the post operative recovery.

The study finding supported by Dube J. V., Kshirsagar N. S., Durgawale P. M., 2014. The study finding showed that less activity after caesarean section found in control group (74.58\%) compared to experimental group (28.16\%) as compare by mean score of both group, control group mean score is more than experimental group on all post operative days from day 2 to day 5 all assessment days data showed that intervention was effective to improve the activities in experimental group than control group ${ }^{21}$

\section{IMPLICATIONS-}

Training programmers and health education for the nurses who are providing care to CS women. nurse should practice early ambulation in ward after 24 hours of CS. The nurse researcher's role is to prepare the mothers to perform daily activity by herself as soon as possible after CS and can also independently holding the baby with the help of early ambulation practice.

\section{MAJOR FINDINGS OF THE STUDY-}

$>$ Women in the experimental group showed a significant increase in the activity of daily living score from day-I$23.77 \pm 2.763$, day-II- 35.37 2.498 and day-III- $45.67 \pm$ 2.564 similarly in control group also there was improvement in the level of activity of daily living score was improving from day-I- $18.17 \pm 1.147$, day-II- $22.53 \pm$ 2.776, and day-III- $32.97 \pm 2.671$ as a result of hospital routine treatment. Which showed that in both the groups, post operative recovery was improving but in the experimental group the post operative recovery was significantly improving than in control group thus it was concluded that the intervention was highly effective in terms of bringing out the improvement in post operative recovery in post operative mothers with CS.

$>$ The same was supported by calculating Independent ' $t$ 'test. The obtained t value was day-I- $t=10.253$, day-II- $t$ $=18.822$ and day-III- $t=18.785$, and overall $p$ value 0.0001 which was more than the table value which indicated that there was significant difference found in both the groups Thus it can interpreted that calculated ' $t$ ' value is more than the tabulated value which showed that intervention was effective to improve the post operative recovery.

$>$ Day wise comparison of within the group was calculated using repeated measure ANNOVA and the obtained $F$ value was 271.094 in experimental group where as in control group F Value was 94.355 at the level of 0.0001 in both the groups, which showed that experimental group day wise difference is much more than control group.

\section{LIMITATIONS-}

Ward routine care is limiting the study in control group

\section{CONCLUSION-}

The study conclude that the early ambulation practice improve early maternal recovery and good sense of wellbeing after CS. the finding of the study revealed that the early ambulation improve the activity of daily living also enhance the post operative recovery after caesarean section and also improve the wellbeing of mother as well as newborn. The investigator main aim behind the study is to make post caesarean women understand the importance of early ambulation and generate enthusiasm among the women to practice by them self. The study finding reveals that early ambulation is effective for improving the post operative recovery

\section{REFERENCES-}

[1] D C Dutta " Text book of Obstetrics ",6 $6^{\text {th }}$ edition, Published by new central book of Agency, 2004; P-134

[2] Brunner and Suddarth's ;Text Book Of Medical Surgical Nursing ;Eleventh edition ;Volume 1 ;Published by Wolters Kluwer(India) Pvt Ltd New Delhi 2008 ; 537.

[3] Jyoti V. Dube \& N. S. Kshirsagar, Effect of Planned Early Recommended Ambulation Technique on Selected Post caesarean Bio physiological Health Parameters, JKIMSU, Vol. 3, No. 1, Jan-June 2014, ISSN 2231-4261 :,41-48 Vol. 3 No. 1 (Jan-June 2014). p65 http://www.jkimsu.com/jkimsuvol3no1/JKIMSU.\%20 Vol.\%203,\%20No.\%201,\%20JanJune\%2 02014,Page\%2 041-48.pdf 